\title{
MANAGEMENT OF SOCIO-ECONOMIC DEVELOPMENT OF TOURISM ENTERPRISES
}

\author{
Svitlana KRYSHTANOVYCH ${ }^{1 *}$, Bogdan KINDZER ${ }^{2}$, Marta GORYN ${ }^{3}$, \\ Alla KRAVCHENKO ${ }^{4}$, Svitlana FRUNZA ${ }^{5}$ \\ ${ }^{1,2}$ State University of Physical Culture named after Ivan Bobersky, Lviv, Ukraine \\ ${ }^{3}$ Ivan Franko National University of Lviv, Lviv, Ukraine \\ ${ }^{4}$ Kyiv National University of Trade, Kyiv, Ukraine \\ ${ }^{5}$ Central Ukrainian National Technical University, Kropyvnytskyi, Ukraine
}

Received 25 February 2020; accepted 29 April 2020

\begin{abstract}
To date, the tourism business is developing rapidly and the mountainous territories are not inferior in competition to other tourist territories. For the development of the tourism business, it is necessary to conduct effective management of socio-economic development. The main purpose of the study is to identify and assess the main threats to the socio-economic development of the tourism business in the mountainous territories of Eastern Europe. We have applied the methods of synthesis, analysis, deduction, induction, mathematical methods, methods of expert research. The importance of research on the management of socio-economic development of the mountains in the conditions of increasing the efficiency of the tourism business is proved. Peculiarities of managing the socio-economic development of the mountains in the conditions of increasing the efficiency of the tourism business are considered. As a result of the study, threats were identified that most negatively affect the management system of the socio-economic development of the tourism business in the mountains. The novelty of the study is the formation of coordinate systems in the trust or distrust of the management and executive staff of travel companies in making management decisions.
\end{abstract}

Keywords: management, socio-economic development, tourism, mountainous areas, threats, enterprises.

JEL Classification: D21, L83, Z32, D81.

\section{Introduction}

Tourism is one of the few sectors of the economy that are able to restore quickly their volumes of activity while creating favorable conditions. The development of tourism enables many countries of the world to receive significant funds in the state budget, to increase the income of related sectors of the economy due to the multiplier effect, to improve the state of the infrastructure of tourist destinations.

Tourism has a special place in the system of sectors of the national economy. As a type of outdoor activity, it is one of the main needs of the population and their expenses. Enterprises serving tourism represent a whole sector of the economy, covering both the tourism industry and the industries that are associated with it indirectly.

These include: transport, communications, trade, construction, agriculture, oil refining, public services, food, light, local industry, etc. (about 60 different industries and sub-sectors of the economy that provide characteristic, related and even non-tourist services which they, however, can use).

In world practice, an understanding of mountain policy has been formed and found application as an instrument for the most complete realization of the economic and social problems of the population living in mountain regions. The development of mountainous territories is a complex socio-economic process that requires clarification of the theoretical and methodological foundations of managing the implementation of mountain policies.

The construction of mechanisms for managing the socio-economic development of mountain territories also requires a local analysis, which should be based on studies of threats that affect the formation of the socio-economic complex of these territories. It is important to assess these threats from the point of view of the functioning of management mechanisms and the ways of implementing the strategy of socio-economic development of mountain

*Corresponding author. E-mail: skrischtanovich@gmail.com 
territories. Mechanisms for the implementation of mountain policy include the development of a strategy and relevant local programs for the socio-economic development of mountain areas, the regulation of economic activity in various areas of their socio-economic complex by executive authorities and local governments for the development of tourism business.

The main purpose of the study is to identify and assess the main threats to the socio-economic development of the tourism business in the mountainous territories of Eastern Europe.

The main subjects of the study are travel companies in Eastern Europe, operating in the mountainous area.

\section{Literature review}

Scientific knowledge about the management issues in the field of socio-economic development of mountainous territories is characterized by a variety of subjectmethodological approaches to the analysis of economic, environmental, legal support of these territories. This is primarily due to the versatility and complexity of the investigated phenomenon itself, as well as to those specific tasks that individual researchers pose. Despite the fact that the problem of managing the socio-economic development of mountainous areas is interdisciplinary in nature, it requires an analysis of some literary sources related to it.

A study of the socio-economic development of the tourism business was conducted by leading scientists: Masyuk (2016), Terebuh (2017), Koshova (2017).

Modern scientific thought gradually demonstrates elements of awareness of the essence of the mountain policy of the state and the study of the features of its implementation, which is crucial in the process of regulating the socio-economic development of mountain territories. There is considerable interest in this regard are the works of Avakyan (2019), Badenkov (2017), Belaya (2019), Golubets (2007), Demchenko (2018), Samoletova (2005), Stadnitsky (2004), Surazakova (2003) and other authors who substantiate conceptual approaches to determining the socio-economic and legal aspects of the implementation of mountain policy.

The problem of state management of the socio-economic development of depressed territories, which include mountains, in the conceptual and institutional dimension was the subject of research by Danylyshyn (2006), Korotich (2010), Nikolaev (2011), Pitukhina (2004), Polishchuk (2009) and other authors. The monograph by Mamonova (2006), which allows to see the complex and contradictory process of state regulation of the socio-economic development of territories, deserves special attention.

Szromek (2019) explored new business models for tourism enterprises. Butler (2019), having also dedicated his research to the selection of business models for enterprises in the tourism industry.

Kozak, Derkach, and Huz (2019) investigated possible options for forming a development strategy for tourism enterprises in the modern conditions of their functioning.

Tourism companies are currently experiencing difficult times because of the epidemic and coronavirus in such moments, a study of their socio-economic development is very relevant. In such a period, it still remains relevant and necessary to determine the main threats to the tourism sector, which even before the epidemic started significantly hindered its socio-economic development.

Methodological approaches to the formation of a common EU regional policy for the development of problematic (depressed areas) are analyzed in the works of Matviishin (2009). Researchers have identified the forms and methods for implementing the joint regional policy of the $\mathrm{EU}$, which takes into account the differentiation of levels of socio-economic development of regions, in particular mountainous, and aims at their gradual convergence.

\section{Methodology and data}

In determining the scientific foundations of the study, the authors proceeded from the complexity and interdisciplinarity of the subject of the study. The theoretical and methodological basis of the work was constituted by the fundamental principles of the theory of public administration, scientific works of domestic and foreign scientists on the management of the socio-economic development of regions and their depressed territories. General scientific and special research methods were used.

Using the analytical method, the selection and analysis of scientific literature on the topic of research was carried out. Historical and logical methods were used to elucidate the theoretical foundations of the development and implementation of mountain policies for the socio-economic development of mountain territories. Comparative and logical-semantic methods were used in the study of mountain development. The comparative method made it possible to generalize European approaches to the management of problem areas, which include mountainous territories, and to consider existing managerial models for their development. Using this method, changes in the development of strategies and programs for the socio-economic development of mountain areas were studied, which then allowed the formation of a mechanism for managing the socio-economic development of mountain areas in the context of increasing the efficiency of the tourism business. For a theoretical generalization and formation of conclusions, an abstract logical method was used.

The expert method for determining threats was already used in their study by Franchuk et al. (2020).

Separately, it is worth highlighting the expert method, with the help of which a survey of leading experts in the field of tourism business in the mountainous territories of Eastern Europe was conducted. The composition and structure of experts includes 20 respondents, 12 of whom have been working in the tourism business for more than 10 years. A survey of experts made it possible to obtain data on the main threats that negatively affect the 
socio-economic development of mountainous areas and the tourism business as a whole (Table 1).

Table 1. Threats to social and economic development, which were received for our study as a result of a survey of leading experts in the field of tourism business in mountainous regions (source: developed by author)

\begin{tabular}{|l|}
\hline \multicolumn{1}{|c|}{ Threats } \\
\hline $\begin{array}{l}\text { Political and economic instability in the territory of tourism } \\
\text { business development }\end{array}$ \\
\hline $\begin{array}{l}\text { Unstable climatic conditions that impede the socio-economic } \\
\text { development of mountainous areas }\end{array}$ \\
\hline Lack of dialogue between top managers and executives \\
\hline $\begin{array}{l}\text { Low state support for the socio-economic development of } \\
\text { mountainous areas }\end{array}$ \\
\hline Growth of inflationary processes \\
\hline $\begin{array}{l}\text { Low infrastructural mountain development in Eastern } \\
\text { Europe }\end{array}$ \\
\hline Low level of safety for tourists \\
\hline
\end{tabular}

We have chosen 20 experts, since it is precisely so many leading experts in the field of tourism that have responded to our request to participate in the study. Our study envisaged the choice of threats to the socio-economic development of the tourism business in the mountainous areas, requiring the choice of only those threats, the most common in the answers of experts.

Separately, for a more detailed analysis of the main threats to the socio-economic development of the tourism business in the mountainous territories, an expert study of two leading enterprises in this field of activity was carried out.

\section{Results and discussions}

In a significant number of countries in Eastern Europe, the volume of tourist spending is growing, only confirms the relevance of improving the management of socio-economic development of the tourism business (Figure 1).

In the context of the strategy of socio-economic development of mountainous areas, tourism plays an exceptional role. Today in many countries of the world it has turned into a large industry, is developing rapidly. As stated in the materials of the Hague Declaration of the InterParliamentary Conference on Tourism: "Tourism can be an effective means of promoting socio-economic growth for all countries if the necessary measures are taken to fulfill the most urgent national tasks and achieve the national economy an acceptable level of self-sufficiency, at which a country should not spend more than what it hopes to receive from tourism.

Changes in the political and economic conditions that took place in Eastern Europe in the 80s of the last century allowed structural reforms in the direction of the prevalence of tourist services over other sectors of the economy, and a focus on the efficient use of tourism potential. Tourism development is manifested in its diversified nature and close factor interdependence with almost all spheres of life, which allows it to be used as an effective tool to stimulate social and economic growth at the national and local levels.

The socio-economic development of the tourism business in the mountainous territories, first of all, is based on three main factors:

- the natural resource potential of mountainous territories and the possibility of its optimal use;

- financial support of economic entities in terms of the possibility of influence from the regional and local administrations;

- organizational and legal support for the effective operation of all sectors of the socio-economic complex of mountainous territories.

To effectively solve the problems of developing the socio-economic complex of mountainous territories (as

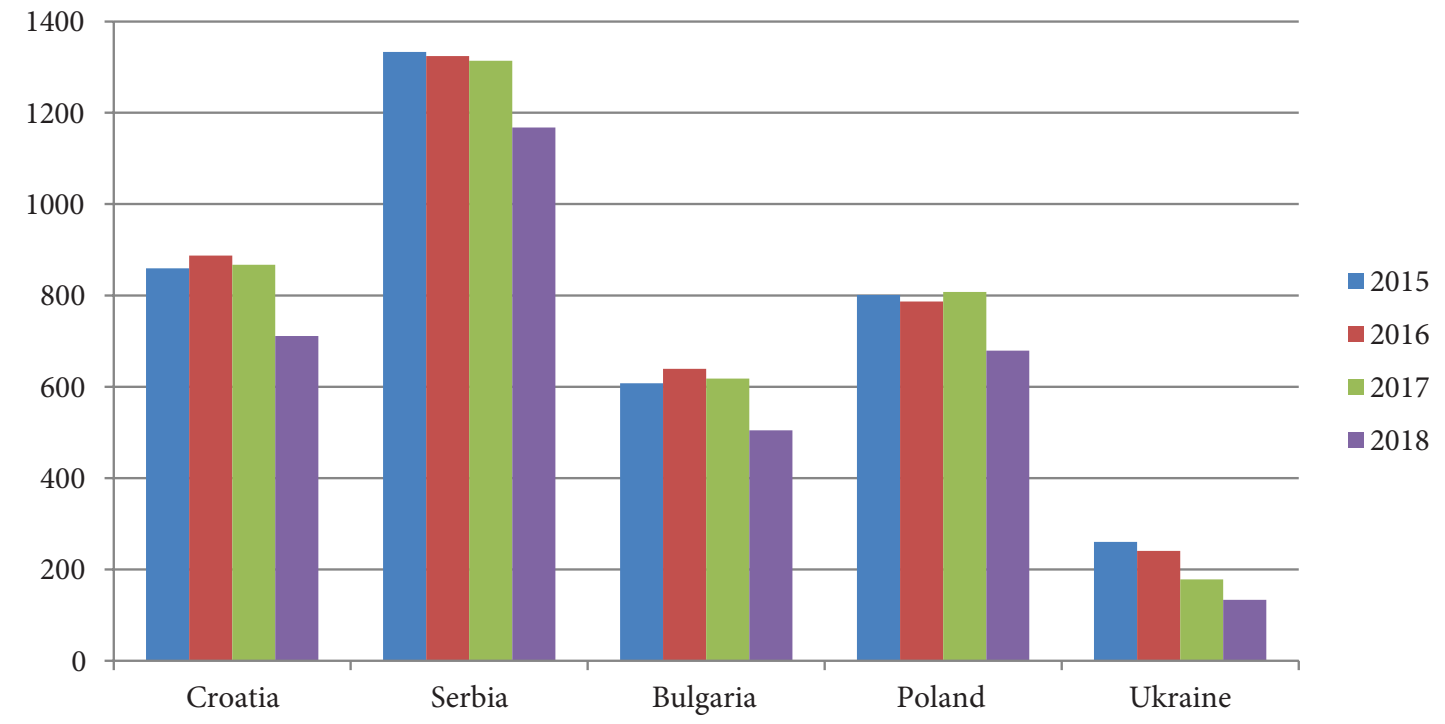

Figure 1. Volumes of expenses of travel companies working with mountainous territories in selected countries of Eastern Europe, millions of US dollars (source: developed by author) 
well as other territories), it is necessary to quickly assess the situation in the economy, make optimal use of existing resources, identify the strengths and weaknesses of the territory and ultimately make informed management decisions. However, this can only be successfully implemented with an appropriate management system [30], which can provide both information-analytical (combining key diagnostic elements for preparing decisions) and organizational-infrastructure (clear distribution of responsibilities, communication efficiency, coordination of actions of the parties involved) components management activities of authorities.

Successful implementation of the mountain policy directly depends on the effective management of the economic, environmental and social development of the mountain territories, in accordance with a pre-developed strategy. Priority areas of implementation are:

- development of infrastructure, primarily transport, road, communication;

- the development of high-tech, energy-saving, hightech and ecophilic industries;

- coordination of activities in the social sphere with the main directions of economic policy on the basis of state and regional programs of socio-economic development;

- ensuring effective employment, preventing unemployment, creating new jobs.

Successful implementation of mountain policy presupposes, first of all, effective state regulation of economic and social processes in mountain territories, provides for a clear distribution of functions and mechanisms for its implementation. It should be noted that the functions of state management of the socio-economic development of mountainous areas determine the specific type of management activity that is objectively necessary to achieve a specific goal. They are relatively isolated in the process of division of labor in the areas of public administration and differ in content, specific forms and methods of developing and exercising influence on managed objects. The main functions of state administration of the socioeconomic development of mountainous areas include the following:

- determination of the goals and objectives of the socio-economic development of mountain areas;

- the formation of strategies, current and long-term programs for the socio-economic development of these territories;

- implementation of an effective financial, credit, budgetary and fiscal policy;

- ensuring environmental and social safety of the population of mountain areas;

- coordination of the interests of all subjects of state administration of the socio-economic development of mountain regions;

- monitoring and analysis of the results of mining policy in the regions;

- control, which includes an assessment of the implementation of targeted programs, normative legal or regulatory acts with the aim of further adjusting the actions and activities of state authorities to stimulate the socio-economic development of mountain territories.

It should be noted that in general, state instruments for implementing mountain policy in the EU countries are divided into the following main groups:

- organizational and institutional mechanism that ensures the implementation of mountain policy;

- administrative and management mechanism (conclusion of regional agreements and contracts);

- the mechanism of spatial planning and the "growth point";

- a mechanism for financial support for the development of mountainous areas (subsidies for certain amounts of investments, loans, financial benefits, subsidies in connection with job creation, etc.);

- economic mechanism (the so-called "soft" means of stimulating the creation of a favorable business environment, the use of regional development agencies, support for consulting activities, the development of cluster development plans, etc.);

- a mechanism for statistical support of programs for the socio-economic development of territories;

- monitoring the effectiveness of planned and implemented measures for the sustainable development of mountain territories.

The effectiveness of the implementation of these tools depends primarily on the organizational and institutional mechanism, which is designed to develop, implement and properly control them. This mechanism for implementing mountain policy in the EU country provides for: an understandable and adequate definition of mountain territories; the availability of opportunities for the mountain population to control the use of natural resources, to solve the problems of free access to land use in mountain territories; possible participation of mountain population in decision-making regarding the socio-economic development of their settlements; their free access to credit; providing effective and efficient incentives to support the development of mountain, green tourism, creating the proper balance between environmental protection and the proper standard of living of mountain people.

Foreign experience in managing the recreational development of mountainous areas, as the leading industry in their socio-economic complex, indicates that the priority areas for the development of this industry are determined taking into account data from sociological studies conducted to identify preferences of different contingents of recreants. So, in Poland, an impulse to the development of the recreational sphere was given by a well-thought-out state policy, which was oriented towards external demand. The state provided tremendous support to small and medium-sized businesses, introducing them to the development of material and specialized transport infrastructure of this industry.

The experience of the EU countries shows that solving the problems of tourism business in mountainous 
areas requires the use of tools such as stimulating "growth points". It should be noted that the concept of "growth point" is quite common, while there is no clear definition of it. As a rule, we are talking about the availability of the necessary conditions and sufficient (necessary) resources, with which the effect of socio-economic growth is achieved.

To disclose the "growth points" of mountain areas at the local level, regional strategies include the use of the following tools:

1. The creation on the basis of clusters of promising "growth points", "areas of economic development", can positively affect the socio-economic development of these territories.

2. "Regional and local availability." The goal is to provide better communications with mountain areas remote from the center through road and transport construction; step up the development of their social infrastructure.

We were interviewed leading experts in the field of socio-economic development of the tourism business in the mountainous territories of Eastern Europe in order to establish, today, the threats have the greatest impact. According to the results of the survey, we streamlined them and determined which of them have the most negative impact on the management of the socio-economic development of the tourism business in the mountainous territories of Eastern Europe (Figure 2).

Take, for example, the problem of the lack of dialogue between top managers and executives on which it is impossible to effectively manage the socio-economic development of the tourism business in the mountainous territories of Eastern Europe. For the study of assessing the level of trust between the management staff and the executive staff, we selected two leading travel companies that are active in the mountainous territories of Eastern Europe and asked them the question "Do you have confidence in the decisions that your leaders make?" and "Do you believe in the effective implementation of your managerial decisions by executive staff?" (Figure 3 ).

The companies that were selected as part of the study were asked to remain anonymous; however, it should be noted that they operate in the Central-Eastern part of Europe.

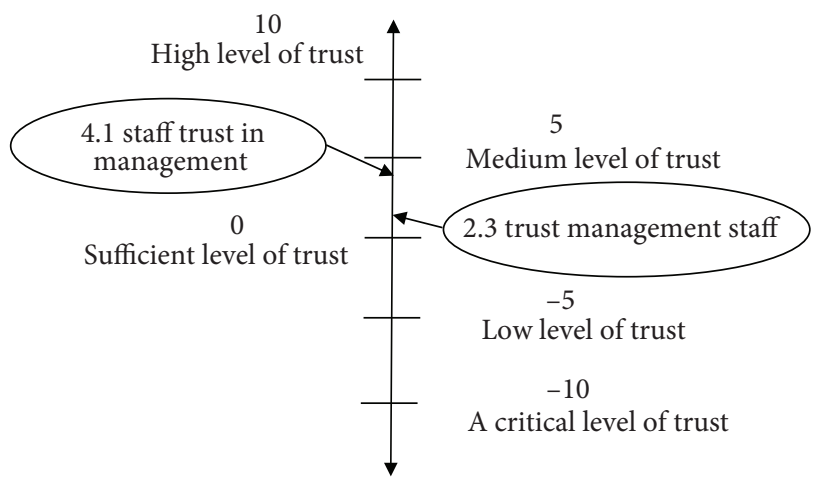

Figure 3. Inter-level streamlining of the main threats to managing the socio-economic development of the tourism business in the mountains (source: developed by author)

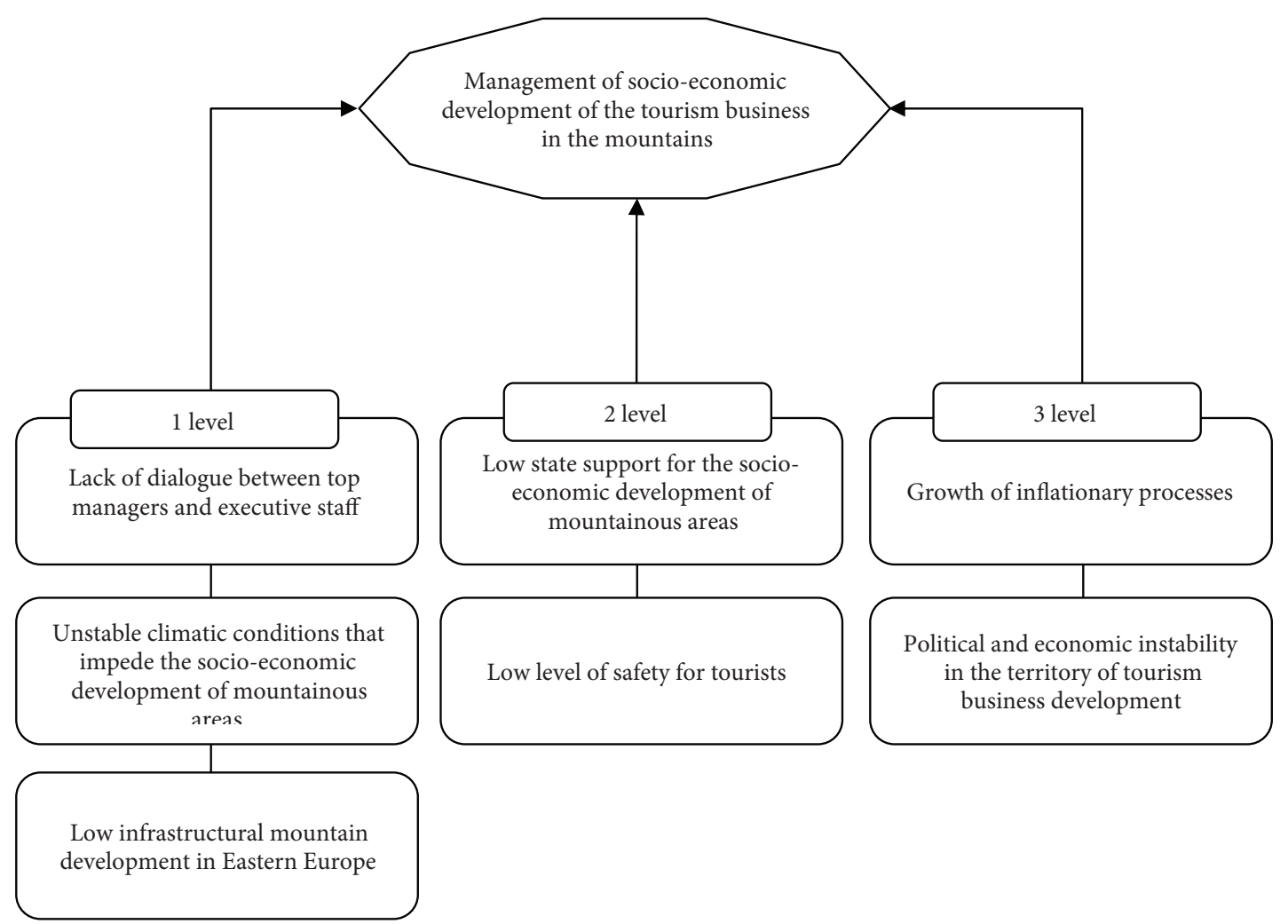

Figure 2. Inter-level streamlining of the main threats to managing the socio-economic development of the tourism business in the mountains (source: developed by author) 


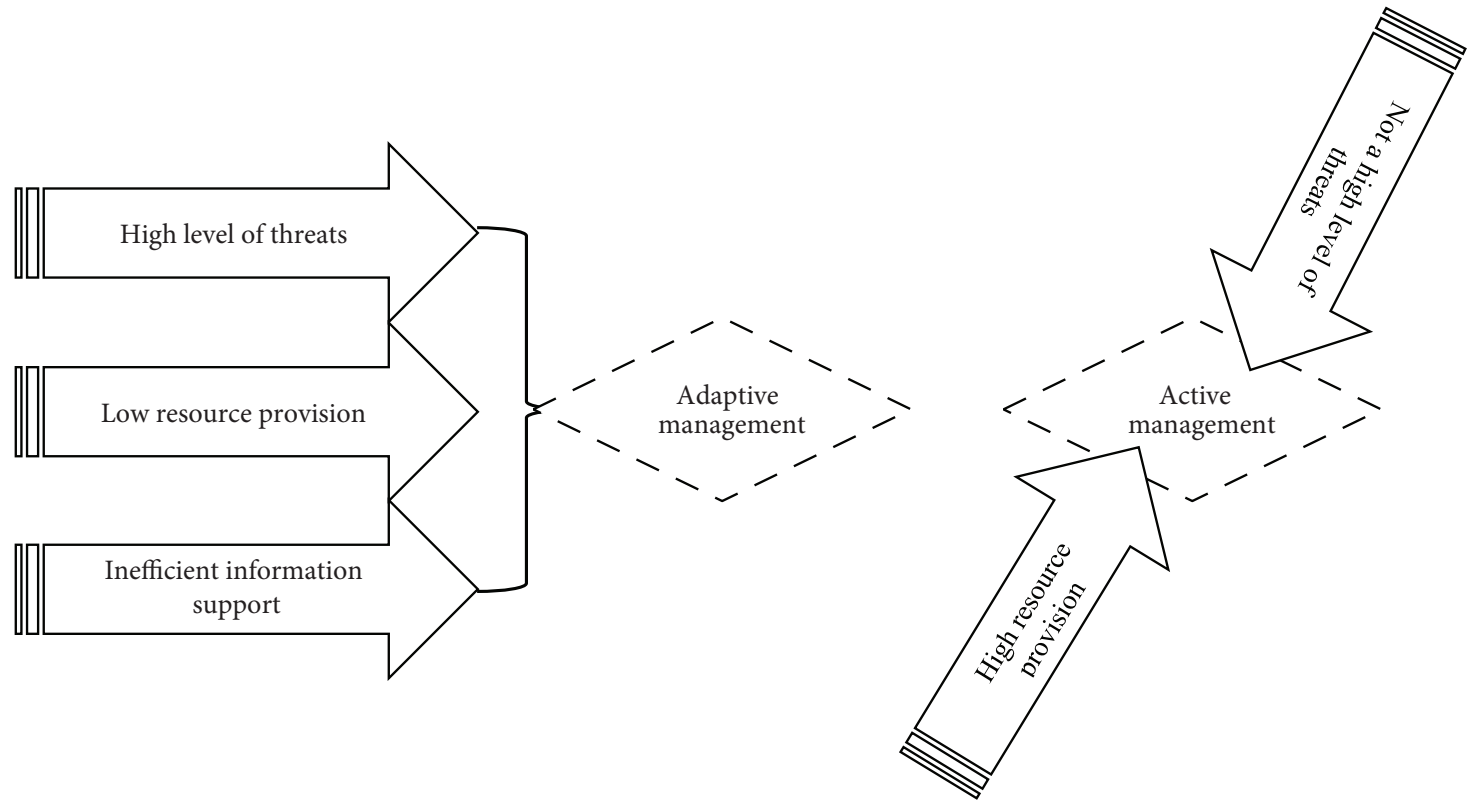

Figure 4. The choice of management strategy for the socio-economic development of the tourism business in the mountains (source: developed by author)

The survey at the enterprises of the tourism industry took place in the context of a rating on a point scale, from 10 to -10 points, respectively, as far as they trust the management and its management.

The results showed that the level of trust is below average, which means that such a threat exists and can have a negative impact on the governance system of the socioeconomic development of the tourism business.

In case of negative influence of threats, it is necessary to choose which type of control should be used. Together with experts, we agreed and identified two main types of management of the socio-economic development of the tourism business in the mountains (Figure 4).

Adaptive management of the socio-economic development of the tourism business in the mountainous territories provides for an analysis of the functioning environment and adaptation to new functioning conditions.

With sufficient resources, it is possible to take and implement measures to directly counter the negative impact of threats.

Despite the category tourism enterprises in the mountain territories fall into, the following areas and tasks in the field of mountain tourism should be:

- study of existing and identifying potential opportunities for the development of mountain tourism;

- development of a mountain tourism development strategy;

- promoting the development of tourism services in the mountains;

- attraction of financial and economic resources of district state administrations, village and village councils, specialized funds for the implementation of pilot projects for the development of mountain tourism;
- standardization and certification of services of tourism entities;

- initiating the development of agro-mountain tourism associations, stimulating the implementation of relevant training programs in the field of "green" tourism, etc.

- creation of an information and consulting center for the development of mountain tourism;

- staffing of various types of tourism in the mountainous territories;

- lobbying for the interests of mountain tourism subjects in government at all levels;

- marketing and advertising in the field of mountain tourism and others.

The priority areas and tasks of management activities in the field of mountain tourism should be: research into existing and identify potential opportunities for the development of mountain tourism; attraction of financial and economic resources of district state administrations, village and village councils, specialized funds for the implementation of pilot projects for the development of tourism in mountainous areas; standardization and certification of services of rural tourism entities; Creation of information and consulting centers for the development of mountain tourism; staffing for mountain tourism; lobbying for the interests of mountain tourism subjects in government bodies; marketing and advertising in the tourism sector and more. More attention should be paid to cooperation with business structures in the tourism industry, which should include the participation not only of tourism entities, but also business entities of related industries, due to the monofunctional direction of tourism. 


\section{Conclusions}

The need to reform and effective development of the socioeconomic complex of mountainous areas should be recognized at all levels of government, as this is the only promising way to solve the socio-economic problems of these territories. But this in no way means that by forcing economic processes in this direction, the desired results will be immediately achieved. Well-balanced decisions and thoughtful practical actions are needed here. Therefore, the further development of the mountainous territories of the studied region should be considered in the context of the structural restructuring of the entire socio-economic complex, in a promising model of which the recreational, health and tourism industries should become one of the main ones.

We, as a result of an expert study, identified threats that have the greatest negative impact on the management system of the socio-economic development of the tourism business in the mountainous territories. As a result, the presence of a partial mistrust of the management and executive staff of travel companies in making management decisions was proved.

As a result of the study of the main threats to the socio-economic development of tourism companies, an inter-level streamlining of the main threats to managing the socio-economic development of the tourism business in the mountains was formed.

In the future, it is necessary to consider in more detail the main aspects of the work of travel companies and develop an effective mechanism for ensuring stable socioeconomic development.

The study is not without limitations. Our study is not without limitations. Unfortunately, our analysis was only part of the tourism industry of individual countries in Eastern Europe.

\section{References}

Avakyan, G. E. (2019). Approaches to the definition of mountain territories. Problems of mining and settlement (214 p.). IG Academy of Sciences of the USSR.

Badenkov, Y. P. (2017). European mountain policy. Socio-economic and legal facts of development (72 p.). Analytical review. Played.

Belaya, S. A. (2019). Institutional support of socio-economic development of problem areas (world experience). Strategic Priorities, 3(12), 172-183.

Butler, R. (2019). Incorporating the value proposition for society with business models of health tourism enterprises. Sustainability, 11(23). https://doi.org/10.3390/su11236711

Danylyshyn, B. M. (2006). Socio-economic problems of the development of regions: methodology and practice. Council for the Study of the Productive Forces of Ukraine (315 p.). ChSTU.
Demchenko, V. V. (2018). Mountain policy in Ukraine: the basics of formation and implementation paths. Regional Economics, $4,237-239$.

Franchuk, V., Omelchuk, O., Melnyk, S., Kelman, M., \& Mykytyuk, O. (2020). Identification the ways of counteraction of the threats to the financial security of high-tech enterprises. Business: Theory and Practice, 21(1), 1-9. https://doi.org/10.3846/btp.2020.11215

Golubets, M. A. (2007). Conceptual foundations of sustainable development of the mountain region (288 p.). Polly.

Korotich, O. B. (2010). State management of the country's regional development: definition of basic concepts. Tomsk State University. Journal Economic Science of Ukraine, 2, 57-61.

Koshova, B. R. (2017). Assessing the impact of socio-economic development on the formation of tourism infrastructure. Western region of Ukraine. Young Scientist, 12, 772-777.

Kozak, Y., Derkach, T., \& Huz, D. (2019). Forming the strategy of integrated development of tourism enterprises. Baltic Journal of Economic Studies, 5(4), 105-115. https://doi.org/10.30525/2256-0742/2019-5-4-105-115

Masyuk, Y. A. (2016). The need for model formation self-regulatory organization in the field of tourism: economic and legal aspects. Bulletin of the University of Lviv, 34, 282- 291. International Relations Series.

Matviishin, E. G. (2009, April 3). Directions of state support for the development of backward and depressed territories: foreign experience. Democratic governance in the context of global challenges and crisis situations: Material sciences conference by international participation (pp. 48-51). Lridu Nagu.

Nikolaev, E. (2011). Problems of using the categorical apparatus of the science of national and socio-economic security. www. politik.org.ua/vid/magcontent.php3?m=1\&n=87\&c=2155

Pitukhina, E. (2004). Different views on sustainable development. Upravlenii by the Academician, 79(15), 84-86.

Polishchuk, V. (2009). Conceptual and categorical apparatus of the policy of stimulating the sustainable development of the region. Actual Problems of The Economy, 11, 168-174.

Samoletova, P. V. (2005). Formation and implementation of a strategy for sustainable development of mountain territories (on the example of the Ukrainian Carpathians) (textbook) (20 p.) Dissertation by Candidate of Economic Sciences 08.10.01. Institute of Regional Studies, National Academy of Sciences of Ukraine. Lviv.

Stadnitsky, Yu. (2004). Sustainable socio-economic development of mountain regions. Region, 3(33), 78-88.

Surazakova, S. P. (2003). On the issue of the model of socio-economic development of mountainous areas. Regional problems of transition to sustainable development, resource potential and its rational use for sustainable development (pp. 157-164). Kemerovo.

Szromek, A. (2019). A business model in Spa tourism enterprises: case study from Poland. Sustainability, 11(10). https://doi.org/10.3390/su11102880

Terebuh, A. A. (2017). Approaches to the evaluation of tourism infrastructure. In Topical problems of economics: Sixteenth International Scientific Seminar. Kiev lake. National Academy of Management. 